\title{
Titanium Oxide Supported on Montmorillonite Clays for Environmental Applications
}

\author{
E. Rigoti,1 A. J. Schwanke, ${ }^{1}$ Karla C. F. Araújo, ${ }^{1}$ C. A. Martínez-Huitle ${ }^{1, *}$ and S. B. C. Pergher ${ }^{1}$ \\ ${ }^{1}$ Institute of Chemistry, Federal University of Rio Grande do Norte, Natal 59078-970, Brazil. Phone/Fax: \\ $+55(84) 3211-9224$
}

*Corresponding author: C. A. Martínez-Huitle, e-mail: carlosmh@quimica.ufrn.br

Received October 13 ${ }^{\text {th }}, 2018$; Accepted June $14^{\text {th }}, 2019$.

DOI: http://dx.doi.org/10.29356/jmcs.v63i3.708

\begin{abstract}
Montmorillonite clays (natural and commercial (KSF and K-10)) were modified by impregnation with $\mathrm{TiO}_{2}$ from $\mathrm{TiCl}_{4}$ solution. The natural and $\mathrm{KSF}$ clays were also pillared with $\mathrm{Al}$ polyhydroxication and after that, these were impregnated with $\mathrm{TiO}_{2}$. Photocatalysts were characterized by X-Ray Diffraction (XRD), Scanning Electron Microscopy (SEM), Energy Dispersive Spectroscopy X-ray (EDX) and Infrared Spectroscopy (IR) in order to understand their catalytic potential properties. Photocatalysts were used in a decomposition reaction of methylene blue (MB) and all catalysts demonstrated photocatalytic activity for degradation of dye (20 to $45 \%$ ); however, K-10 sample showed the best results (more than $98 \%$ of elimination) due to its high superficial area and $\mathrm{TiO}_{2}$ dispersion. The results obtained using photocatalysts were compared with electrochemical oxidation process using Ti/Pt anode, showing that the photocatalysis reaction is more efficient. At present, our results demonstrate the potential of these catalysts for environment applications.

Keywords: methylene blue; montomillonite; pillared clays; photocatalysis; catalysts; electrochemical oxidation.

Resumen. Las arcillas de montmorillonita (naturales y comerciales (KSF y K-10)) se modificaron por impregnación con $\mathrm{TiO}_{2}$ a partir de una solución de $\mathrm{TiCl}_{4}$. Las arcillas naturales y KSF también se agruparon con polihidroxilación de $\mathrm{Al}$ y, posteriormente, se impregnaron con $\mathrm{TiO}_{2}$. Los fotocatalizadores se caracterizaron mediante difracción de rayos-X (XRD), microscopía electrónica de barrido (SEM), espectroscopía de rayos-X de dispersión de energía (EDX) y espectroscopia de infrarrojo (IR) con el objetivo de comprender sus propiedades catalíticas. Los fotocatalizadores se emplearon en una reacción de descomposición de azul de metileno (MB) y todos los materiales sintetizados mostraron actividad fotocatalítica para la degradación del colorante (20 a 45\%). Sin embargo, el fotocatalizador K-10 mostró los mejores resultados (más del 98\% de eliminación) debido a su alta área superficial y la dispersión de $\mathrm{TiO}_{2}$. Los resultados obtenidos utilizando los fotocatalizadores se compararon con el proceso de oxidación electroquímica utilizando ánodo Ti/Pt, evidenciando que la reacción de fotocatálisis es más eficiente. Nuestros resultados muestran el potencial de estos catalizadores para aplicaciones ambientales.
\end{abstract}

Palabras clave: azul de metileno; montmorillonita; arcillas pilares; fotocatálisis; catalizadores; oxidación electroquímica.

\section{Introduction}

Water pollution by textile dyes has major environmental problems. The color removal of an effluent is as important as the removal of toxicity of the colorless organic substrates because the presence of small amounts of dye $\left(<1 \mathrm{mg} \mathrm{L}^{-1}\right)$ is clearly visible [1] and can influence considerably the water by changes in biological cycles [2]. 
Effluent treatment technologies involving transference phase are efficient for color removal; however, they do not eliminate the problem, only change the pollutant from the liquid phase to the solid phase.

Advanced oxidation processes (AOPs) are an alternative for the treatment of effluents because they are more sustainable in the long-term. Oxidizing agents $\left(\mathrm{O}_{3}, \mathrm{H}_{2} \mathrm{O}_{2}\right)$ and/or catalysts $\left(\mathrm{Fe}, \mathrm{Mn}, \mathrm{TiO}_{2}\right)$ may be used in the presence or absence of the radiation source for generating hydroxyl free radicals $\left({ }^{\circ} \mathrm{OH}\right)$ capable to mineralize the organic pollutants into non-toxic compounds, such as $\mathrm{CO}_{2}$ and $\mathrm{H}_{2} \mathrm{O}$ [3].

Among AOPs, heterogeneous photocatalysis is the most widely used approach. In this process, the activation of the semiconductor occurs by sunlight or artificial light irradiation. The absorption of photons with energy greater than the bandgap region between the valence band (VB) and conduction band (CB) promotes an electron from VB to $\mathrm{CB}$, generating a gap in the valence band. The potential of these gaps depends on the semiconductor and $\mathrm{pH}$. These potentials are positive enough to generate ${ }^{\circ} \mathrm{OH}$ radicals from water molecules adsorbed on the surface of the semiconductor which, in turn, can oxidize the organic contaminants [4].

$\mathrm{TiO}_{2}$ is one of the most widely used photocatalysts due to its high photosensitivity, which can be used in the environment. It is non-toxic and has high bandgap energy [5, 6]. Recently, some reviews have described the use of $\mathrm{TiO}_{2}$ in different heterogeneous oxidation processes for eliminating different types of contaminants [7-9]. Some studies have reported the use of $\mathrm{TiO}_{2}$ in aqueous suspensions [10-12]. It is used in the form of ultrafine powders with high specific surface area; and thus, it has good catalytic activity. Therefore, the use of $\mathrm{TiO}_{2}$ in the form of nanoparticles [13,14], nanofibers [15] or films on metallic and non-metallic [16] surfaces or supported on different materials has been studied by some researchers. Such supports may be activated carbon [9, 17], zeolites [18], diatomite [19], natural clays such as kaolinite [20, 21], hectorite [21] as well as the montmorillonites type clays with titanium incorporated in the form of pillars [22-28]. These studies have shown that the dispersion of $\mathrm{TiO}_{2}$ particles with high surface area on a support is a viable solution to the problem of recovery of these materials.

The main objective of this work was to study the use of montmorillonite clay as $\mathrm{TiO}_{2}$ support and after that, these catalysts were employed as photocatalysts in the decomposition of MB. Based on the existing literature, no attempts have been published until now about the application of K-10 and KSF as photocatalysts for removing organic pollutants. As a evaluation method, the photocatalysts efficiency for depollution of synthetic dye effluent was compared with the electrochemical oxidation process.

MB was chosen as model organic pollutant because it is widely used in the biology (e.g., bacteriology) and chemical (e.g., redox indicator) fields. It is used as a drug and as an antidote specific for cyanide. The concern is the use of textile dye for dyeing denim fabrics and veterinary use. Therefore, the amount of MB in the effluent must be properly monitored and eliminated before its disposal.

\section{Materials and Methods}

The dye used in photodecomposition reactions was MB in a solution of $20 \mathrm{mg} \mathrm{L}^{-1}$. For preparing the catalysts, two commercial clays, K-10 and KSF (Sigma-Aldrich) and natural clay (AN) provided by Petrosix (São Mateus do Sul - PR - Brazil) were employed. The AN and KSF clay were also pillared with polihidroxications of $\mathrm{Al}$ (KSFP and ANP) [29]. These materials were used in the impregnation $\mathrm{Of}^{\mathrm{TiO}} 2$ by using titanium tetrachloride (IV) (Merck) and cyclohexane (Merck). In the case of electrochemical oxidation experiments, $\mathrm{H}_{2} \mathrm{SO}_{4}$ was purchased from Fluka. The dyestuff solution was prepared dissolving $\mathrm{MB}\left(20 \mathrm{mg} \mathrm{L}^{-1}\right)$ in distilled wastewater containing $0.5 \mathrm{M} \mathrm{H}_{2} \mathrm{SO}_{4}$.

\section{Pillarization of Polihidroxication of Aluminum}

The clay samples (natural and KSF) were pillared according to the following procedure: $1.5 \mathrm{~g}$ of treated clay was placed in suspension with $150 \mathrm{~mL}$ of $\mathrm{H}_{2} \mathrm{O}$ under stirring for $2 \mathrm{~h}$. Then, $300 \mathrm{~mL}$ of pillarizing agent with 16.6 meq $\mathrm{Al} \mathrm{g}^{-1}$ was added. The pillarizing agent was prepared by the slow addition of $200 \mathrm{~mL}$ of sodium hydroxide $0.25 \mathrm{~mol} \mathrm{~L}^{-1}$ to $100 \mathrm{~mL}$ of aluminum chloride $0.25 \mathrm{~mol} \mathrm{~L}^{-1}$ and aged for $6 \mathrm{~d}$. The clay/pillarizing agent mixture was stirred for $2 \mathrm{~h}$, after which was filtered and dried at $100^{\circ} \mathrm{C}$ for $12 \mathrm{~h}$.

The samples were calcined at $450^{\circ} \mathrm{C}$ for $3 \mathrm{~h}$ according to the following program: heating from $25^{\circ} \mathrm{C}$ up to $150^{\circ} \mathrm{C}$ at a heating rate of $5^{\circ} \mathrm{C} \mathrm{min}^{-1}$, maintaining the temperature for $30 \mathrm{~min}$, heating from 150 to $450^{\circ} \mathrm{C}$ at a heating rate of $5^{\circ} \mathrm{C} \mathrm{min}^{-1}$, maintaining at $450{ }^{\circ} \mathrm{C}$ for $3 \mathrm{~h}$. 


\section{$\mathrm{TiO}_{2}$ Impregnation}

$\mathrm{TiO}_{2}$ was incorporated into the material so as to obtain $10 \%$ of Ti on clays. To this, $0.4 \mathrm{~mL}$ of a $\mathrm{TiCl}_{4}$ solution was used in cyclohexane (Merck) with the addition of $0.2 \mathrm{~g}$ of clay. The solution was stirred for $1 \mathrm{~h}$ at $100^{\circ} \mathrm{C}$. Later, the samples were calcined in air at $350^{\circ} \mathrm{C}$ for $4 \mathrm{~h}$, so that titanium oxide was formed in all samples.

\section{Material characterizations}

The starting materials and catalysts were characterized by X-ray diffraction in a DIFFRAKTOMETER - Model D5000 (Siemens) and nickel filter using Cu-k $\alpha$ radiation $(\lambda=1.54 \AA)$. The analysis of the amount of titanium incorporated was carried out by energy dispersive spectroscopy X-ray (EDX) in scanning electron microscope JEOL equipment - JSM 5800.

The analysis of $\mathrm{N}_{2}$ adsorption was also performed to verify variations in the surface area of the materials during the preparation process and after $\mathrm{TiO}_{2}$ incorporation. These analyses were performed by nitrogen adsorption using a Quantachrome Autosorb-1 device (New 2200e).

The analysis of IR-spectroscopy was performed on spectrophotometer Shimadzu FTIR model 8300. The spectrum was obtained with 32 scans and $4 \mathrm{~cm}^{-1}$ resolution. For analysis, the sample was prepared in the form of tablets of approximately $2 \mathrm{~mm}$ of thickness and $5 \mathrm{~mm}$ in diameter. A dilution of about $10 \%$ of the sample was accomplished using $\mathrm{KBr}$.

\section{Photodecomposition Reaction}

The photodegradation of MB was performed by using as catalysts, the materials impregnated with $\mathrm{TiO}_{2}$. A total of $50 \mathrm{mg}$ of catalyst in $200 \mathrm{~mL}$ of $\mathrm{MB}$ solution $\left(20 \mathrm{mg} \mathrm{L}^{-1}\right)$ was submitted to photochemical reaction in a photo-reactor equipped with a mercury lamp (TQ 718 of $250 \mathrm{~W}$, from Heraeus Noblelight Company in Germany) passing UV light at wavelengths shorter than $280 \mathrm{~nm}$. The reactor was cylindrical (25 $\mathrm{cm} \times 5 \mathrm{~cm}$ of diameter), with a capacity of $0.5 \mathrm{~L}$, and it was made of quartz glass for transmittance of radiation. Temperature and $\mathrm{pH}$ were also measured at the beginning and at the end of each one of the experiments. The amount of catalyst was chosen based on the studies reported in the literature [7-12]. UV-visible technique, by using Shimadzu UV-160A at wavelength of $665 \mathrm{~nm}$, was employed to determine the discoloration of synthetic effluent; withdrawing aliquots of $2 \mathrm{~mL}$ from the solution at different times $(5,10,20,30$ and $60 \mathrm{~min})$.

\section{Electrooxidation Experiments}

Bulk oxidations were performed in undivided electrochemical cell, the reaction compartment having a capacity of $200 \mathrm{~mL}$, and the solution was stirred by a magnetic stirrer. The experiments of MB oxidation were carried out under galvanostatic conditions using a MINIPA 1013 power supply. Ti-supported Pt anode was supplied by Industrie De Nora S.p.A. (Milan, Italy). Ti/Pt was used as the anode, and titanium as the cathode. Both electrodes were square, each one of them with $15 \mathrm{~cm}^{2}$ geometrical area. The temperature of the electrolyte was controlled using a water thermostat. Experiments were performed at $25^{\circ} \mathrm{C}$ for studying the role of applied current density $(10,30$ and $50 \mathrm{~mA} \mathrm{~cm}$ ); furthermore, the effects of the temperature and agitation rate were also investigated, carrying out experiments in the range from 25 to $60^{\circ} \mathrm{C}$, and 300,500 and $620 \mathrm{rpm}$, respectively, under a current density of $30 \mathrm{~mA} \mathrm{~cm}^{-2}$.

\section{Analytical Methods} expression:

Experimentally, discoloration efficiency or percentage of color removal is determined by the

$$
\text { colour removal }=\left(\frac{\left[A B S_{0}-A B S_{t}\right]}{A B S_{0}}\right) \times 100
$$

where $\mathrm{ABS}_{0}$ and $\mathrm{ABS}_{\mathrm{t}}$ are the average absorbance values before electrolysis and after an electrolysis time $\mathrm{t}$, respectively, at the maximum visible wavelength $(\lambda \max )$ of the wastewater. 


\section{Results and discussion}

\section{Materials characterization}

In the diffractograms of the starting materials before the impregnation with $\mathrm{TiO}_{2}$, it was observed that these materials are clays of the family of montmorillonite (20 6) (Fig. 1). The first peak (001) refers to the basal spacing between the layers. It was observed that when the natural clay is pillared, this peak (001) is shifted from $\sim 6$ (or 9.7 when calcined) to 5 , indicating an increase in the basal spacing from $15 \AA$ (or $10 \AA$ when calcinated) to $18.5 \AA$.
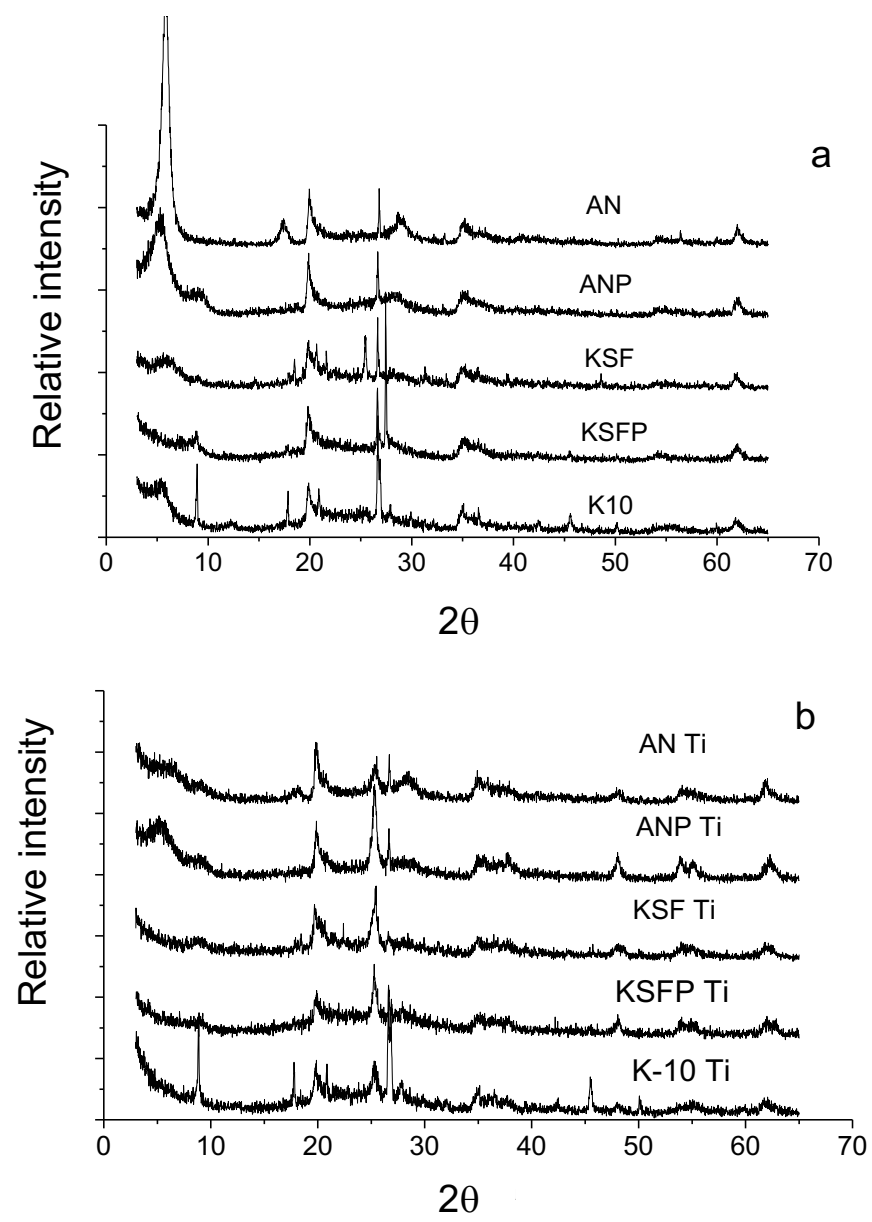

Fig. 1. X-ray diffraction of materials after (a) and before (b) $\mathrm{TiO}_{2}$ impregnation.

In the diffractograms of KSF and K-10 samples, it was observed that the intensity of this peak (001) is smaller than that presented by natural and pillared clays. This is due to the fact that, these materials are disordered in axis c, because these were prepared from the acidic treatments.

In the pillaring process of the KSF material, at first, XRD did not indicate an organization of the pillaring structure. However, there was an increase in the surface area (Table 1) which suggests that the pillaring process promoted that the material to be more accessible, in terms of porosity. The increase in the surface area of other materials indicates that the pillaring process was effective. 
Table 1. Specific photocatalysts surface areas before and after the $\mathrm{TiO}_{2}$ incorporation in the starting materials.

\begin{tabular}{ccc} 
Sample & Before incorporation $\left(\mathbf{m}^{\mathbf{2}} \mathbf{g}^{-\mathbf{1}}\right)$ & $\mathbf{A f t e r} \mathbf{~ \mathbf { ~ i O }} \mathbf{2}$ incorporation $\left(\mathbf{m}^{\mathbf{2}} \mathbf{g}^{-\mathbf{1}}\right)$ \\
\hline AN & 32 & 54 \\
ANP & 224 & 141 \\
KSF & 12 & 53 \\
KSFP & 92 & 116 \\
K-10 & 224 & 204 \\
\hline
\end{tabular}

K-10 clay has high surface area due to the strong acid treatment used for the preparation of this material. $\mathrm{H}_{2} \mathrm{SO}_{4}$ treatment at elevated temperatures disorganizes the structure with the removal of $\mathrm{Fe}, \mathrm{Mg}$ and $\mathrm{Al}$ from the structure, making the solid more mesoporous [30]. In previous works [31], in the pillaring process, K-10 clay showed a decrease on the surface area, which is not of interest for the incorporation of $\mathrm{TiO}_{2}$. Therefore, this material was not used in the MB degradation. Fig. 1 also shows the XRD patterns of the material after the incorporation of $\mathrm{TiO}_{2}$. After the addition of $\mathrm{TiO}_{2}$ in the non-pillared clay, a decrease in peak 001 was observed; this is because in the interlayer region, the oxides of titanium replacing the hydrated cations, generating a decrease in the basal spacing. Meanwhile, in the pillared clays, the diffractogram practically remains equal, indicating in the case of pillared natural clay that the incorporation of titanium oxide did not affect the basal spacing formed by the pillars of aluminum oxide.

After incorporation of $\mathrm{TiO}_{2}$ in the materials, except for the pillared natural and $\mathrm{K}-10$ clays, there was a small increase in surface area that is probably attributed to the incorporation of these oxides in the interlayer region acting as $\mathrm{TiO}_{2}$ pillars, making this region accessible for surface area measurements with the $\mathrm{N}_{2}$ molecule. In the case of $\mathrm{K}-10$, the small decrease in surface area can also be attributed to the incorporation of $\mathrm{TiO}_{2}$ in the interlayer region, directing an organization of same layers of K-10. Similar process occurred when polyhydroxycation of aluminum was incorporated on K-10 clay [31]. In the pillared natural clay, $\mathrm{TiO}_{2}$ incorporation on interlayer region probably blocked the pores reducing the accessibility of $\mathrm{N}_{2}$ molecules for surface area measurements. It was also observed the presence of peaks that are a characteristic of titanium anatase phase in the positions $2 \theta=25.4$ and 48.3 and $54.9^{\circ}$.

According to SEM analysis for these materials (Fig. 2), the results clearly showed that all photocatalysts have the lamellar morphology indicating that the layer are maintained during the pilarization process and incorporation of $\mathrm{TiO}_{2}$. It was also observed that small clusters after the addition of $\mathrm{TiO}_{2}$ were formed, until on outer surface.

Fig. 3 shows the infrared spectroscopy analysis, indicating that characteristic vibrations of clay montmorillonite structure at $600-1200 \mathrm{~cm}^{-1}$ were observed, according to Stubica and Rog assignment [32]. The bandwidth centered at $\sim 1038 \mathrm{~cm}^{-1}$ shows the combination of stretching and deformation vibration of Si-O related to basal oxygen atoms. The band at $\sim 930 \mathrm{~cm}^{-1}$ is due to the $\mathrm{OH}$ group linked to $\mathrm{Al}$ atoms. The band at $\sim 1650 \mathrm{~cm}^{-1}$ represents the interaction of $\mathrm{OH}$ with oxygen in the structure. There were no changes in the spectra with the pillaring process, indicating again that the clay layer was maintained.

After impregnation with $\mathrm{TiO}_{2}$, a slight decrease on the band was observed, regarding the montmorillonite $600-1200 \mathrm{~cm}^{-1}$, indicating again a little disorganization of the structure. EDX analysis of clay impregnated with $\mathrm{TiO}_{2}$ (Table 2) showed that almost all samples, except for clay K-10, showed Ti percentage (mass) above $10 \%$. This can be explained by the fact that the EDX analysis was only superficial, indicating that $\mathrm{TiO}_{2}$ incorporation also occurred on the outer surface. However, it can be considered that the samples are $10 \%$ of Ti by weight of the total. 

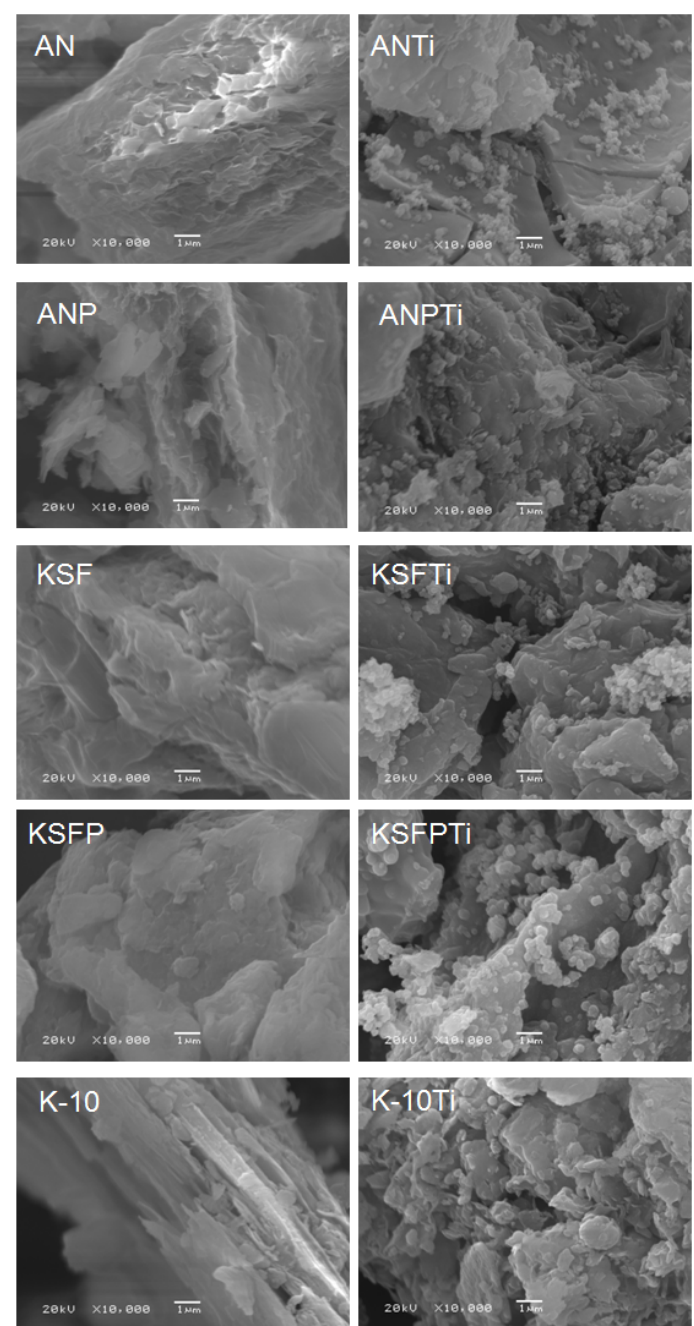

Fig. 2. Micrographs of materials before (AN, ANP, KSF, KSFP and K-10) and after the impregnation of Ti (ANTi, ANPTi, KSFTi, KSFPTi and K-10Ti).

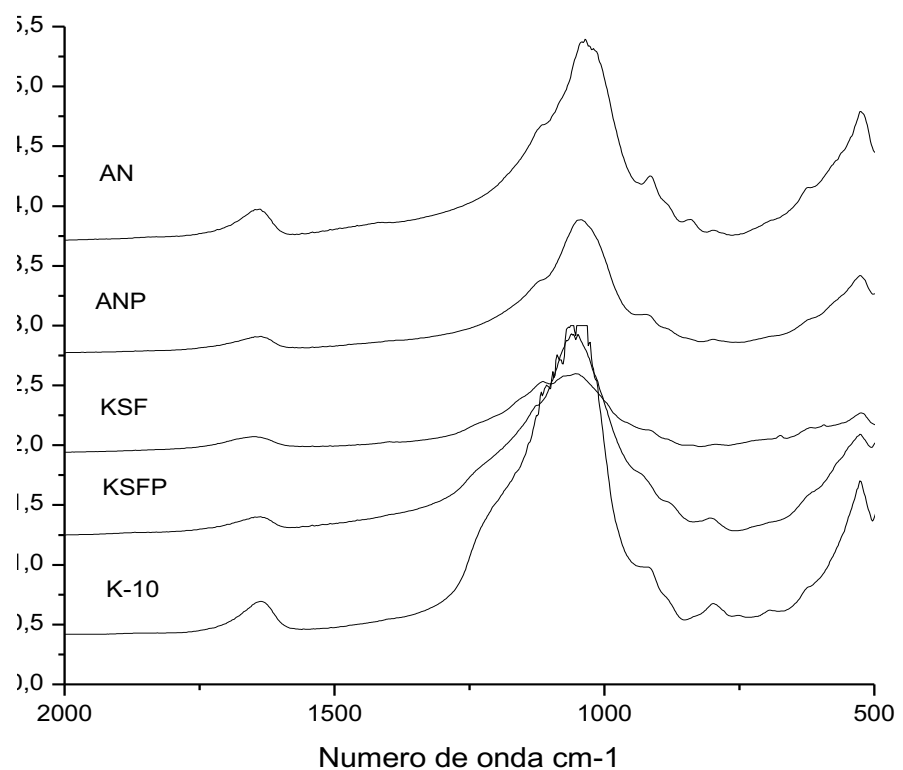

Fig. 3. UV spectrum of materials after (a) and before (b) $\mathrm{TiO}_{2}$ incorporation. 


\section{Photocatalysis elimination of MB}

The heterogeneous photocatalysis is one of many options among AOPs, where a photocatalyst $\left(\mathrm{TiO}_{2}\right.$, $\mathrm{CdS}, \mathrm{ZnO}, \mathrm{WO}_{3}, \mathrm{ZnS}, \mathrm{BiO}_{3}, \mathrm{Fe}_{2} \mathrm{O}_{3}$ ) is irradiated with a UV light source (natural or artificial) to form on its surface a pair electron $\left(\mathrm{e}^{-}\right) / \operatorname{gap}\left(\mathrm{H}^{+}\right)$sites and oxidants [33]. In these active sites, reactions may occur with the species such as oxygen, water molecules and hydroxyl ions that will form highly reactive species such as hydroxyl radicals $\left({ }^{\circ} \mathrm{OH}\right)$. These radicals will act both in the degradation of organic and inorganic pollutants, as in the reduction of metals present in aqueous, gaseous and solid ecosystems.

The efficiency of this process is to harness energy absorbed by the photocatalyst (a very fast reaction), preventing its dissipation as recombination reaction [33]. The presence of donor and acceptor electron among species can prevent the spread of this reaction. The oxygen dissolved in the medium acts as acceptor electron, as well as water and metal ions.

The route most significant formation of radical ${ }^{\bullet} \mathrm{OH}$ is related to the reaction of water molecules or $\mathrm{OH}$ groups, in the gap $\left(\mathrm{h}^{+}\right)$photogenerated in the valence band (BV) of the semiconductor, shown in Eqs. (1) (3) $[33-37]$.

$$
\begin{aligned}
& \mathrm{TiO}_{2}+h v \rightarrow \mathrm{TiO}_{2}\left(\mathrm{~h}^{+}{ }_{\mathrm{BV}}+\mathrm{e}^{-}{ }_{\mathrm{BC}}\right) \\
& \mathrm{H}_{2} \mathrm{O}+\mathrm{h}^{+}{ }_{\mathrm{BV}} \rightarrow{ }^{\bullet} \mathrm{OH}+\mathrm{H}^{+} \\
& \mathrm{OH}^{-}+\mathrm{h}^{+}{ }_{\mathrm{BV}} \rightarrow{ }^{\bullet} \mathrm{OH}
\end{aligned}
$$

Oxygen has the function of scavenging the electron conduction band (CB), forming the superoxide ion $\left(\mathrm{O}_{2} \bullet^{-}\right)$as Equation 4, retarding the recombination reactions of $\mathrm{e}^{-} / \mathrm{h}^{+}$. This ion can promote a series of chain reactions (Equation 5-8) and $\mathrm{H}_{2} \mathrm{O}_{2}$ formed from this molecule to generate more hydroxyl radicals (Equation 911) $[33-37]$.

$$
\begin{aligned}
& \mathrm{O}_{2}+\mathrm{e}^{-} \mathrm{BC} \rightarrow \mathrm{O}_{2}^{\bullet-} \\
& \mathrm{O}_{2}^{\bullet-}+\mathrm{H}^{+} \rightarrow \mathrm{HO}_{2}^{\bullet} \\
& \mathrm{HO}_{2}^{\bullet}+\mathrm{HO}_{2}^{\bullet} \rightarrow \mathrm{H}_{2} \mathrm{O}_{2}+\mathrm{O}_{2} \\
& \mathrm{O}_{2}^{\bullet-}+\mathrm{HO}_{2}^{\bullet} \rightarrow \mathrm{HO}_{2}^{-}+\mathrm{O}_{2} \\
& \mathrm{HO}_{2}^{-}+\mathrm{H}^{+} \rightarrow \mathrm{H}_{2} \mathrm{O}_{2} \\
& \mathrm{H}_{2} \mathrm{O}_{2}+\mathrm{e}^{-}{ }_{\mathrm{BC}} \rightarrow{ }^{\bullet} \mathrm{OH}+\mathrm{OH}^{-} \\
& \mathrm{H}_{2} \mathrm{O}_{2}+\mathrm{O}_{2}^{\bullet-} \rightarrow{ }^{\bullet} \mathrm{OH}+\mathrm{O}_{2} \\
& \mathrm{H}_{2} \mathrm{O}_{2}+h v \rightarrow 2 \cdot \mathrm{OH}
\end{aligned}
$$

In recent years, many research groups have investigated the application of AOPs to remove dyes from wastewaters [34-39]. Total removal of the organic load and color are the primary objectives of these AOPs, as established by Brazilian environmental laws [36]. In this context, photocatalytic decomposition reactions were 
tested by using prepared photocatalysts, after that, the elimination of MB was monitored by UV-visible technique. Fig. 4 shows the color removal efficiencies for all photocatalysts; nevertheless K-10 showed the best performance in the MB decomposition than the other ones. In 60 minutes, a complete color removal of MB (20 $\mathrm{mg} \mathrm{L}^{-1}$ ) from solution was accomplished, confirming the catalytic properties to promote photocatalytic reactions. Natural clay, pillared natural clay, KSF and pillared KSF photocatalysts showed lower decomposition activity, ranging from 20 to $45 \%$ of color removal. The high activity of K-10 was related to its larger surface area and better $\mathrm{TiO}_{2}$ distribution on its surface, as confirmed by results obtained during characterization and surface chemistry of this material. Furthermore, K-10 contains a higher number of active sites due to its larger surface area [31], which facilitated the reactions with the species present in the medium, such as oxygen, water molecules and hydroxyl ions that will form highly reactive hydroxyl radicals $\left({ }^{\circ} \mathrm{OH}\right)$, according to equations (411) [33-37]. After that, ${ }^{\bullet} \mathrm{OH}$ radicals formed, equations (12-14), contributed to complete oxidation of the organic compounds, in this case, the dye [35-37]:

$$
\begin{aligned}
& \mathrm{H}_{2} \mathrm{O} \rightarrow \cdot{ }^{\bullet} \mathrm{OH}+\mathrm{H}^{+}+e \\
& \cdot \mathrm{OH} \rightarrow \mathrm{O}_{2}+\mathrm{H}^{+}+e \\
& \text { dyes } \stackrel{\cdot \mathrm{OH}}{\longrightarrow} \mathrm{CO}_{2}+\mathrm{H}_{2} \mathrm{O}
\end{aligned}
$$

Conversely, unimportant removal efficiency was achieved by the other photocatalysts due to the limited production of oxidizing species in the medium $\left({ }^{\circ} \mathrm{OH}\right)$. However, it is important to evaluate if MB removal occurred through adsorption, photocatalytic reactions or via both processes. Then, an adsorption experiment was conducted by using the same amount of catalyst but in absence of irradiation under agitation conditions. As can be observed in Fig. 4, no significant color removal was achieved after 60 min, indicating that the main process is due to the photocatalytic reaction by using K-10.

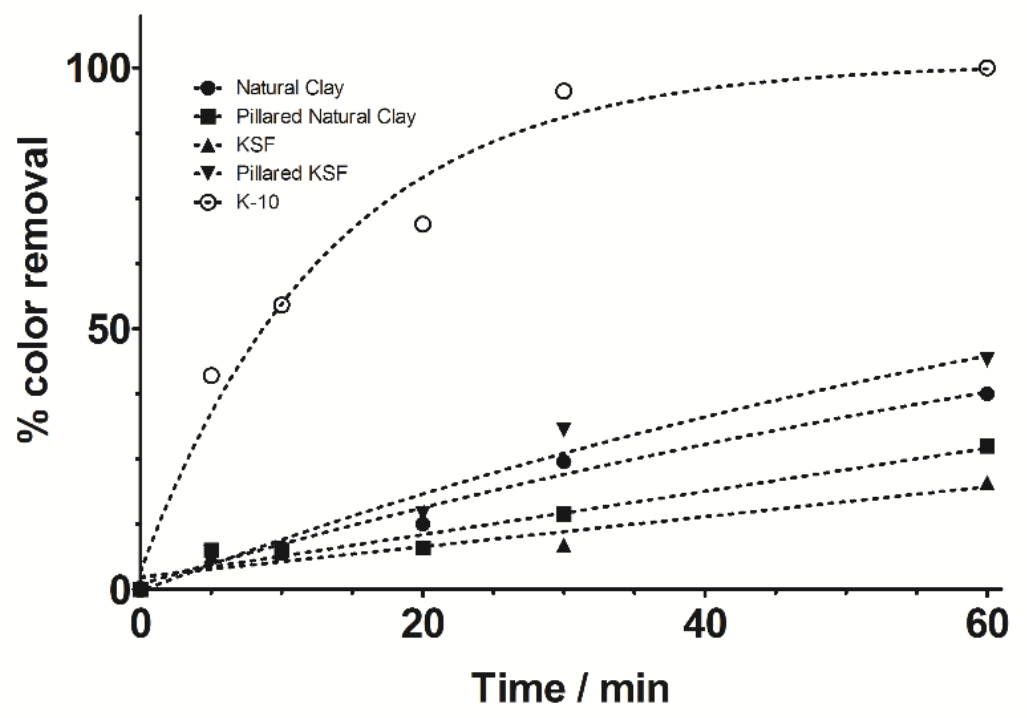

Fig. 4. \% of color removal, as a function of time, for the MB decomposition by using different photocatalysts. 
In the case of K-10, as can be seen in Fig. 5, a decrease on the absorbance bands of MB dye (600, 660 and $750 \mathrm{~nm}$ ) was observed, as a function of reaction time. This behavior indicated that the dye degradation occurred by fragmentation of the chemical structure of MB (breaking of the chromophore group) by reaction with ${ }^{\circ} \mathrm{OH}$ radicals produced during the photocatalytic reaction, and after that, forming other simple organic compounds [33-37]. According to Brazilian laws, textile factories employ specific methods for removing color from wastewaters (biological or physicochemical treatments) and therefore, the discoloration process is monitored. Thus, the residual color in the effluent from the textile industry should be less than 300 Hazen units. As can be seen from the tests using K-10, color removal was obtained, reaching the legal Brazilian requirements [40]. These results suggested that the photocatalytic process, using catalysts prepared here, could be used as an alternative to removal color from industrial wastewaters. To study the kinetics of the overall reaction involved in the disappearance of MB by photocatalysis, was considered the decay of dye concentration for each one of the photocatalysts. Results given in Fig. 6 were further analyzed using kinetic equations and good linear plots were obtained for all cases, when the MB concentration decays were fitted to a pseudo-first-order reaction $\left(\operatorname{In}\left(\mathrm{C}_{0} / \mathrm{C}_{\mathrm{t}}\right)\right.$ vs time). As can be seen in Fig. 6, this behavior was found for all photocatalysts up to 60 min, giving a pseudo-rate constants $(\mathrm{k})$ of $7.74 \times 10^{-3} \mathrm{~min}^{-1}\left(r^{2}=0.99\right)$ for natural clay, $4.91 \times 10^{-3} \mathrm{~min}^{-1}\left(r^{2}=0.99\right)$ for pillared natural clay, $3.25 \times 10^{-3} \mathrm{~min}^{-1}\left(r^{2}=0.99\right)$ for KSF, $9.90 \times 10^{-3} \mathrm{~min}^{-1}\left(r^{2}=0.98\right)$ for pillared KSF and $1.01 \times 10^{-1} \mathrm{~min}^{-1}$ $\left(r^{2}=0.98\right)$ for K-10. This result suggested that K-10 photocatalyst showed a higher removal rate of MB, and also that, it was possible to infer that the concentration of all oxidizing species $\left({ }^{\circ} \mathrm{OH}\right)$ depends on the photocatalyst used [37].

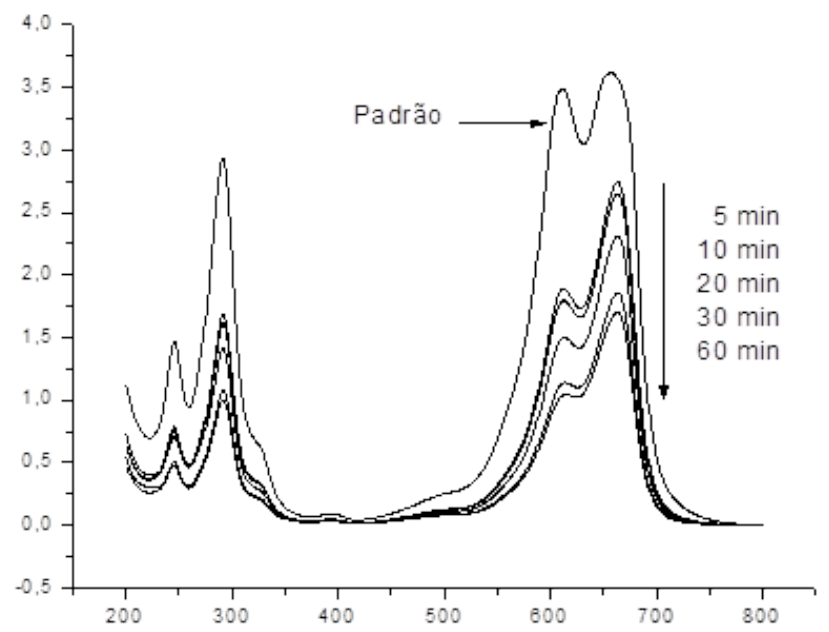

Fig. 5. UV-Vis spectra for the MB solution using K-10 sample at different reaction times.

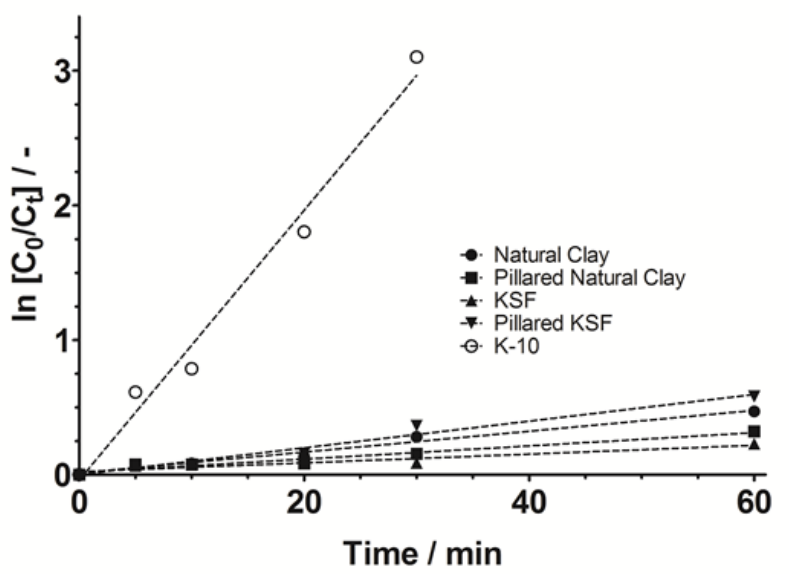

Fig. 6. Kinetic analysis for the pseudo-first-order reaction of MB discoloration using photocatalytic process. 


\section{Electrochemical elimination of MB}

To understand the efficiency of the photocatalysts prepared here, we have proposed the comparison between two AOPs: photocatalytic and electrochemical oxidation for removing MB from solutions. Then, Fig. 7 shows the influence on applied current density on the color removal by disappearance of absorbance bands (inset); during electrochemical oxidation of synthetic waste containing MB $\left(20 \mathrm{mg} \mathrm{L}^{-1}\right)$. As it can be observed, the complete color removal was achieved independently of the applied current density, in all cases. Nevertheless, it should be mentioned that the discoloration rate increased when the applied current density was increased (Fig. 7). This behavior indicated that the dye elimination through direct anodic (adsorption dye molecules to electrode surface) and indirect oxidations by means of its reaction with electrogenerated ${ }^{\circ} \mathrm{OH}$ radicals. However, under similar conditions of MB concentration used at photocatalytic process, complete color removal was attained after $180 \mathrm{~min}$ by electrolysis treatment. These results clearly showed that electrochemical degradation occurred slower than that achieved by photocatalysis treatment. This behavior suggested that the activation of photocatalysis and formation of strong oxidant species by irradiation steps, was rapid than those electrochemical reactions attained at Ti/Pt surface.

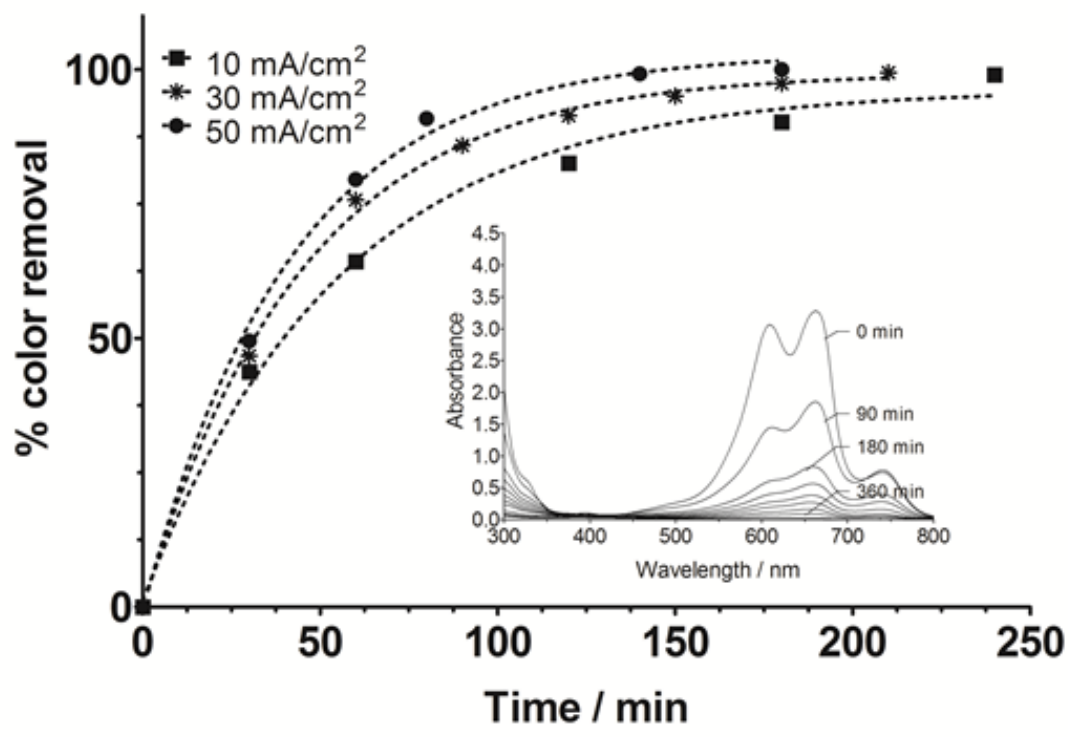

Fig. 7. Influence of applied current density on the color removal during $\mathrm{MB}$ anodic oxidation using Ti/Pt electrode. Inset: visible spectrum of the $\mathrm{MB}$, decreasing as a function of time. Operating conditions: $[\mathrm{MB}]_{0}$ $=20 \mathrm{mg} \mathrm{L}{ }^{-1}$, electrolyte: $0.5 \mathrm{M} \mathrm{H}_{2} \mathrm{SO}_{4}$, temperature $\mathrm{T}=25^{\circ} \mathrm{C}$.

On the other hand, it is important to remark that, the oxidants produced in solution, suffered chemical activation by irradiation (photocatalysis) and after that, other strong oxidant species can be produced by the combination of the oxidant produced with another species which leads to the production of very reactive species, such as ozone and hydrogen peroxide [34-37]. Conversely, the reactivity of many the raw oxidants produced in the electrochemical processes was not very high and some sort of activation was often required to obtain a clear improvement of the processes. In this frame, these assumptions explain the higher removal efficiencies observed when K-10 photocatalyst was used for degrading MB. In contrast, when electrochemical treatment was employed, the production of oxidants was attained on Ti/Pt, but their efficiency was limited by their lower chemical activation, obtaining complete MB removals at longer times. 


\section{Conclusion}

The materials prepared based on montmorillonite clays were successfully impregnated with $\mathrm{TiO}_{2}$ and these were active in the MB decomposition. The most active photocatalyst was $\mathrm{K}-10$ commercial clay, without pilarization process. This material presented highest surface area and good $\mathrm{TiO}_{2}$ distribution, justifying the efficient performances in the MB decomposition, favoring the efficient production of strong oxidant species. Moreover, the discoloration time was minor than that achieved at electrochemical treatment, demonstrating that these photocatalytic materials may be considered promising in the treatment of textile effluents.

Further tests should be carried out in order to study the amount of catalyst to be used to improve the removal efficiency and monitoring the photocatalytic reaction intermediates to determine the complete removal of the organic load. Although the results of color removal and reduction of the MB concentration in solutions are not indicative of complete removal of the organic load, as demonstrated by other authors using electrochemical process [41], it is important to note that these preliminary results point to the high efficiency of this process to treat effluents when compared with other advanced oxidation processes, such as electrochemical oxidation. The energy of the photocatalytic process $(0.45 \mathrm{kWh})$ is minor than that employed in the electrochemical treatment, when a current of $10 \mathrm{~mA} \mathrm{~cm} \mathrm{~cm}^{-2}\left(33.60 \mathrm{~m}^{-3} \mathrm{kWh}\right)$. Furthermore, treatment times are short (less than $1 \mathrm{~h}$ ) in comparison with the time spent in the electrochemical treatment. Thus, these types of catalysts may be a viable process for discoloration of wastewater or process as a pre-treatment step preceding the biological treatment significantly reducing treatment cost and time. Further experiments are in progress to test the photocatalysts in presence of solar light for removing organic matter from a real textile effluent produced by a Brazilian industry.

\section{Acknowledgment}

Financial support from National Council for Scientific and Technological Development (CNPq - 465571/20140; CNPq - 446846/2014-7 and CNPq - 401519/2014-7) and FAPESP (2014/50945-4 are gratefully acknowledged).

\section{References}

1. Clausen, D.N.; Takashima, K. Quim. Nova. 2007, 30, 1896-1899.

2. Byrne, J.A.; Fernandez-Ibañez, P.A.; Dunlop, P.S.M.; Alrousan, D.M.A.; Hamilton, J.W.J. Int. J. Photoenergy. 2011, 2011, 1-12.

3. Singh, H.K.; Saquib, M.; Haque, M.M.; Muneer, M. Chem. Eng. J. 2008, 136, 77-81.

4. Nogueira, R.F.P.; Jardim, W.F. J. Chem. Educ. 1993, 70, 863-864.

5. Faisal, M.; Tariq, M.A.; Muneer, M. Dyes Pigm. 2007, 72, 233-239.

6. Jiaguo, Y.; Mietek, J.; Gongxuan, L. Int. J. Photoenergy. 2012, 2012, 1-5.

7. Rajeshwar, K.; Osugi, M.E.; Chammanee, W.; Chenthamarakshan, C.R.; Zanoni, M.V.B.; Kajitvichyanukul, P.; Krishnan-Ayer, R. J. Photochem. Photobiol. C. 2008, 9, 171-192.

8. Han, F.; Kambala, V.S.R.; Srinivasan, M.; Rajarathnam, D.; Naidu, R. App. Catal. A. 2009, 359, 2540.

9. Puma, G.L.; Bono, A.; Krishnaiah, D.; Collin, J.G. J. Hazard. Mater. 2008, 157, 209-219.

10. Saquib, M.; Tariq, M.A.; Haque, M.M.; Muneer, M. 2008, 88, 300-306.

11. Bergamini, R.B.M.; Azevedo, E.B.; de Araújo, L.R.R. Chem. Eng. J. 2009, 149, 215-220.

12. Cernigoj, U.; Stangar, U.L.; Trebse, P.; Sarakha, M. J. Photochem. Photobiol. A. 2009, 201, 142-150.

13. Tian, G.; Fu, H.; Jing, L.; Tian, C. J. Hazard. Mater. 2009, 161, 1122-1130.

14. Mahvi, A.H.; Ghanbarian, M.; Nasseri, S.; Khairi, A. Desalination. 2009, 239, 309-316.

15. Chong, M.N.; Jin, B.; Zhu, H.Y.; Crow, C.W.K.; Saint, C. Chem. Eng. J., 2009, 150, 49-54.

16. Liu, R.; Li, S.; Yu, X.; Zhang, G.; Ma, Y.; Yao, J. J. Mater. Chem. 2011, 21, 14917-14924.

17. Zhou, W.; Zhang, P.; Liu, W. Int. J. Photoenergy, 2012, 2012, 1-7.

18. Chatti, R.; Rayalu, S.S.; Dubey, N.; Labhsetwar, N.; Devotta, S. Sol. Energy Mater. Sol. Cell. 2007, 91, 180-190. 
19. Zheng, S.; Bai, C.; Gao, R. Int. J. Photoenergy 2012, 2012, 1-4.

20. Chong, M.N.; Vimonses, V.; Lei, S.; Jin, B.; Chow, C.; Saint, C. Microporous Mesoporous Mater. 2009, 117, 233-242.

21. Kibanova, D.; Trejo, M.; Destaillants, H.; Cervini-Silva, J. Appl. Clay Sci. 2009, 42, 563-568.

22. Yang, X.; Zhu, H.; Liu, J.; Gao, X.; Martens, W.N.; Frost, R.L.; Shen, Y.; Yuan, Z. Microporous Mesopouros Mater. 2008, 112, 32-44.

23. Zhu, H.Y.; Li, J.Y.; Zhao, J.C.; Churchman, G.J. Appl. Clay Sci. 2005, 28, 79-88.

24. Rezala, H.; Khalaf, H.; Valverde, J.L.; Romero, A.; Molinari, A.; Maldotti, A. Appl. Catal. A. 2009, 352, 234-242.

25. Damardji, B.; Khalaf, H.; Duclaux, L.; David, B. Appl. Clay Sci. 2009, 45, 98-104.

26. Zhang, G.; Ding, X.; He, F.; Yu, X.; Zhou, J.; Hu, Y; Xie, J. J. Phys. Chem. Solids. 2008, 69, 11021106.

27. Dvininov, E.; Popovici, E.; Pode, R.; Cocheci, L.; Barvinschi, P.; Nica, V. J. Hazard. Mater. 2009, 167, 1050-1056.

28. Liu, J.; Dong, M.; Zuo, S.; Yu, Y. Appl. Clay Sci. 2009, 43, 156-159.

29. Corma, A.; Fornes, V.; Pergher, S.B.; Maesen, Th.L.M.; Buglass, J.G. Nature, 1998, 396, 353-356.

30. Cseri, T.; Békássy, S.; Figueras, F.; Cseke, E.; Menorval, L.; Dutartre, R. Appl. Catal. A. 1995, 132, 141-155.

31. Rossa, V.; Spazzini, S.T.; Schwanke, A.J.; Penha, F.G.; Pergher, S.B.C. $30^{a}$ Reunião Anual da Sociedade Brasileira de Química. 2007, 21-22.

32. Tichit, D.; Fajula, F.; Figueiras, F.; Ducourant, B.; Mascherpa, G.; Gueguen C.; Bousquet, J. Clays Clay Miner. 1998, 36, 369-375.

33. Cervantes, T.N.M.; Zaia, D.A.M.; Santana, H. Quim. Nova. 2009, 32, 2423-2428.

34. Warang, T.; Patel, N.; Santini, A.; Bazzanella, N.; Kale, A.; Miotello, A. Appl. Catal. A, 2012, 423424, 21-27.

35. Petkowicz, D.I.; Brambilla, R.; Radtke, C.; Silva da Silva, C.D.; da Rocha, Z.N., Pergher, S.B.C.; dos Santos, J.H.Z. Appl. Catal. A, 2009, 357, 125-134.

36. Sapawe, N.; Jalil, A.A.; Triwahyono, S.; Sah, R.N.R.A.; Jusoh, N.W.C.; Hairom, N.H.H.; Efendi. J. Appl. Catal. A. 2013, 456, 144-158.

37. Matos, J.; García A.; Park, S.-E. Appl. Catal. A. 2011, 393, 359-366.

38. Brillas, E.; Martínez-Huitle, C.A. Appl. Catal. B Environ. 2015, 166-167, 603-643.

39. Forgacs, E.; Cserhati, T.; Oros, G., Environ. Int. 2004, 30, 953-971.

40. CONAMA, Environmental Brazilian Laws: Resolução Conselho Nacional de Meio Ambiente. Diário Oficial da União, 2005, 18, 58-63.

41. Oliveira, G. R.; Fernandes, N. S.; de Melo, J. V.; da Silva, D. R.; Urgeghe, C.; Martínez-Huitle, C.A. Chem. Eng. J. 2011, 168, 208-214. 